\title{
The effect of feeding frequency, water temperature, and stocking density on the growth of river puffer Takifugu obscurus reared in a zero-exchange water system
}

Gwang-Yeol Yoo ${ }^{1}$ and Jeong-Yeol Lee $2^{2^{*}}$

\begin{abstract}
The effects of daily feeding frequency (Exp I), water temperature (Exp II), and stocking density (Exp III) on the growth of river puffer, Takifugu obscurus, juvenile fish of 10 and $40 \mathrm{~g}$ in body weight were examined to develop effective techniques to produce river puffer in a non-exchange water system. In Exp I, fish were fed commercial floating feed with $45 \%$ protein one to five times per day to apparent satiation each by hand daily for 8 weeks at $25^{\circ} \mathrm{C}$. In both the 10- and 40-g size groups, the final body weight, daily feed consumption, and weight gain of fish fed one meal per day were significantly lower than those of fish fed five meals per day $(P<0.05)$. However, there were no significant differences in the final body weight, daily feed consumption, and weight gain among fish fed two, three, and five meals per day. Feed efficiency showed decreasing tendency with increasing size of fish. In Exp $\mathrm{II}$, fish of 10 and $40 \mathrm{~g}$ in initial body weight were reared with the commercial feed at $15-30^{\circ} \mathrm{C}$ for 8 weeks. The weight gain of fish increased with raising water temperature up to $25^{\circ} \mathrm{C}$ and decreased drastically at $30{ }^{\circ} \mathrm{C}$ for both sizes. The Q10 of specific growth rate was decreased with raising water temperature from 5.04 (temperature interval, $\left.15-20^{\circ} \mathrm{C}\right)$ to $0.66\left(25-30^{\circ} \mathrm{C}\right)$ for the $10-\mathrm{g}$ fish and from 4.98 to 0.31 for the $40-\mathrm{g}$ fish. In Exp III, the effect of stocking density on growth was examined with fish of 10 and $40 \mathrm{~g}$ in initial body weight. The final body weight for initial stocking densities of 4,8 , and $12 \mathrm{~kg} / \mathrm{m}^{3}$ was significantly higher than that of $20 \mathrm{~kg} / \mathrm{m}^{3}$ for the $10-\mathrm{g}$ fish, and the final stocking density reached $10.1,19.2,28.7$, and $39.9 \mathrm{~kg} / \mathrm{m}^{3}$, respectively. For the $40-\mathrm{g}$ fish, the final body weight for initial stocking densities of 3 and $6 \mathrm{~kg} / \mathrm{m}^{3}$ was significantly higher than that of 9 and $15 \mathrm{~kg} / \mathrm{m}^{3}$ and the final stocking density reached $7.38,13.5,17.1$, and $27.5 \mathrm{~kg} / \mathrm{m}^{3}$, respectively $(P<0.05)$. In both groups, weight gain tended to decrease with increasing stocking density; however, survival showed no significant difference.
\end{abstract}

Keywords: Takifugu obscurus, Feeding frequency, Stocking density, Water temperature, Q10

\section{Background}

There are over 100 different species of puffers in the world (Bai et al. 1999). Among them, tiger puffer, Takifugu rubripes, and river puffer, Takifugu obscurus, are the main culture species. River puffer is distributed in the south-western and the south-eastern seawaters of Korea and China, respectively (Kato et al. 2005). River puffer moves from sea to river for reproduction during the spawning season of May to June in Korea. Therefore,

\footnotetext{
* Correspondence: yjeong@kunsan.ac.kr

${ }^{2}$ Department of Aquaculture and Aquatic Science, Kunsan National

University, Gunsan 54150, South Korea

Full list of author information is available at the end of the article
}

it has typical anadromous life history (Yang and Chen 2004). River puffer is one of the promising cultured fish species in South Korea because of its desirable taste and high market price (Ministry of Oceans and Fisheries 2013).

The current commercial culture practice involves the growing of fingerlings with a size of $2-5 \mathrm{~g}$ using floating net cages along the coast or indoor recirculating aquaculture system (RAS). River puffer takes 30 months to grow to marketable size, $400 \mathrm{~g}$. One of the most serious problems in the aquaculture of river puffer is the extremely low productivity that is linked with high mortalities from outbreaks of parasitic diseases as shown in tiger puffer (Kikuchi et al. 2006). Survival through the 
production period is estimated to be less than $50 \%$, and prospects for developing methods for the prevention and treatment of diseases remain as a major challenge faced by aquaculture enterprise. Nevertheless, the river puffer is a promising candidate for aquaculture production because of its high market price being more than four times that of olive flounder and rock fish (Ministry of Oceans and Fisheries 2013).

In recent years, a new production technology, based on mixed biofloc communities, has been implemented in shrimp and tilapia production because they feature high production yield, water quality control, and feed protein recycling simultaneously in the same culture unit (Avnimelech 2006; Crab et al. 2007; Little et al. 2008). Such units are known as intensive zero-exchange systems (BFT), and they utilize direct carbon inputs (sugar or molasses) to promote the growth of biofloc communities (McIntosh 2001; Burford et al. 2004). Mixed biofloc communities remove ammonia-nitrogen from the water and assimilate it directly into bacterial biomass. Containing as much as $34 \%$ crude protein (Tacon et al. 2002), this bacterial biomass has been shown to contribute substantially to fish nutrition, thereby potentially deducing feed costs, lowering production costs, and improving the overall economics of the system (Moss 2002; Samocha et al. 2004; Azim and Little 2008). This also reduces equipment and energy costs for the production system by eliminating the need for external components such as biofiltration, disinfection through ultraviolet light or ozonation, and possibly solid filtration.

Key biological parameters, such as nitrogenous waste levels, effects of water temperature, and impacts of stocking density on growth, and proper feed composition need to be determined for a specific species in order to develop a profitable production system (Kikuchi et al. 2006). Previous investigations on the river puffer, however, have focused mainly on the development of larvae and juvenile, reproductive physiology, and seed production (Jang et al. 1996; Park et al. 1997; Son et al. 2001; Yang and Chen 2004; Kato et al. 2005; Yang and Chen 2006). We confirmed that BFT tank (217 \%) showed a higher weight gain than the running seawater tank (164\%) in a preliminary study where 5-g-size river puffers were carried out in BFT tank and running seawater tank for 8 weeks (unpublished data). However, information for developing a cost-effective, zero-exchange system for this species is still scarce. Therefore, the objective of the present study was to evaluate the effects of feeding frequency, water temperature, and stocking density on the growth of river puffer in non-exchange water mixed biofloc community systems.

\section{Methods}

River puffers produced by Chungcheongnam-do Fishery Research Institute were reared with commercial diet
(Woosong, Daejeon, South Korea) at $20{ }^{\circ} \mathrm{C}$ until the start of the experiments. The experiments were conducted in six circular concrete tanks (two tanks have an inner diameter of $6 \mathrm{~m}$ and height of $1 \mathrm{~m}$, and four tanks have an inner diameter of $3 \mathrm{~m}$ and height of $0.8 \mathrm{~m}$ ) illuminated by $100-\mathrm{lx}$ fluorescent light during the day (07:00-19:00). Each tank was filled with 20-psu seawater and was aerated and agitated continuously using pipe diffusers connected to an air pump. Fish (average weight of $13 \pm 4.8 \mathrm{~g}$ ) were stocked in each tank with an initial stocking density of approximately $2 \mathrm{~kg} / \mathrm{m}^{3}$. Fish were grown without intentional water exchange until the end of feeding trials and were fed twice daily at 09:00 and 17:00 with floating commercial feed containing $45 \%$ crude protein (Woosong, Daejeon, South Korea) at $2 \%$ of total fish weight per day. Molasses $(44 \% \mathrm{C})$ was added in each tank as an external carbon source to be the estimated $\mathrm{C}: \mathrm{N}$ ratio of 15 (Avnimelech 2007). The $\mathrm{pH}$ was maintained between 7 and 8, and alkalinity was kept between 100 and $150 \mathrm{mg} / \mathrm{L} \mathrm{CaCO}_{3}$ by periodic addition of $\mathrm{NaHCO}_{3}$. Dissolved oxygen concentration was maintained greater than $4.0 \mathrm{mg} / \mathrm{L}$. After 50 days of rearing experiments, feeding trials were conducted by installing plastic cages in each rearing tank. A tight net of $10 \mathrm{~cm}$ was lined inside the plastic cages to prevent feed loss through the wall and bottom of the cages.

The effect of temperature on the rate of the physiological processes is generally expressed as Q10, where

$$
\mathrm{Q} 10=(\mathrm{R} 1 / \mathrm{R} 2)^{10 /(\mathrm{T} 1-\mathrm{T} 2)}
$$

$\mathrm{R} 1$ and R2 are specific growth rate (SGR) at a higher and lower temperature, respectively, and T1 and T2 are the higher and lower temperatures, respectively.

Throughout the experimental period, water temperature, salinity, dissolved oxygen (DO), and $\mathrm{pH}$ were measured daily at 08:00-10:00 h using YSI 556 (YSI, Inc., Yellow Springs, USA). Water samples $(50 \mathrm{~mL})$ were collected twice a week at 14:00 h from each tank. Half of the water sample was analyzed spectrophotometrically for total ammonia-nitrogen (TAN) and nitrite nitrogen $\left(\mathrm{NO}_{2}-\mathrm{N}\right)$ following the Standard methods for the examination of water and wastewater (APHA 1998); the remaining half was filtered under vacuum pressure through predried and preweighed GF/C filter paper. The filter paper containing suspended materials was dried at $105{ }^{\circ} \mathrm{C}$ in an oven until constant weight, and the dried sample was weighed to $0.01 \mathrm{mg}$. The weight difference and the total suspended solids (TSS) were calculated. Alkalinity was determined twice a week by titration (Hach digital titrator, Hach, Loveland, CO, USA).

All data were subjected to one-way ANOVA using SPSS for Windows (release 14.0). When a significant treatment effect was observed, Duncan's multiple range 
test was used to compare means. Treatment effects were considered significant at $P \leq 0.05$.

\section{Feeding frequency}

The effect of feeding frequency on the growth of river puffer was examined with fish of 10 and $40 \mathrm{~g}$ in initial body weight. Thirty and 20 fish with average body weight of 10 and $40 \mathrm{~g}$, respectively, were stocked in plastic cages. Plastic cages $(0.5 \times 0.4 \times 0.3 \mathrm{~m})$ were placed in a tank (inner diameter of $6 \mathrm{~m}$, height of $1 \mathrm{~m}$ ). Fish were fed floating commercial pellet feed one, two, three, and five meals per day to apparent satiation by hand. Each feeding group was triplicated, and the experiment lasted for a period of 8 weeks. Any uneaten food was collected, and feed intake was calculated for each meal as feed provided minus feed waste. Feeding was conducted between 07:30 and 08:00 for the once daily feeding; 07:30 and 08:00 and 17:30 and 18:00 for the twice daily feeding; 07:30 and 08:00, 12:30 and 13:00, and 17:30 and 18:00 for the three times feeding; and 07:30 and 08:00, 10:00 and 10:30, 12:30 and 13:00, 15:00 and 15:30, and 17:30 and 18:00 for the five times feeding. Water temperature was maintained at $25 \pm 1{ }^{\circ} \mathrm{C}$.

\section{Water temperature}

The effect of water temperature on the growth of river puffer was examined with fish of 10 and $40 \mathrm{~g}$ in initial body weight. Fish were stocked in plastic cages $(0.5 \times 0.4 \times 0.3 \mathrm{~m})$ in four rearing experiment tanks (inner diameter of $3 \mathrm{~m}$, height of $0.8 \mathrm{~m}$ ), and water temperature of rearing tanks was controlled using a heat pump at $15 \pm 1,20 \pm 1,25 \pm 1$, and $30 \pm 1{ }^{\circ} \mathrm{C}$. Thirty fish of 10 -g size and 20 fish of 40 -g size were distributed randomly to each plastic cage and were fed floating commercial pellet feed in triplicate groups at twice a day to apparent satiation each by hand for 8 weeks. Prior to the rearing experiment, fish were acclimated to each experimental temperature during a week.

\section{Stocking density}

The effect of stocking density on the growth of river puffer was studied using two size groups, 10 and $40 \mathrm{~g}$. Fish averaging $10 \mathrm{~g}$ were randomly distributed to floating plastic cages $0.4 \times 0.17 \times 0.3 \mathrm{~m}$ in a group of 8 , 16,24 , and 40 at a density of $4,8,12$, and $20 \mathrm{~kg} / \mathrm{m}^{3}$, respectively. Fish in the second size group with average weight of $40 \mathrm{~g}$ were distributed to floating plastic cages of $0.6 \times 0.45 \times 0.3 \mathrm{~m}$ in a group of $6,12,18$, and 30 fish at a density of $3,6,9$, and $15 \mathrm{~kg} / \mathrm{m}^{3}$, respectively. The plastic cages were randomly assigned to triplicate groups of each stocking density in the experimental tank (inner diameter of $6 \mathrm{~m}$, height of $1 \mathrm{~m}$ ). Fish in both size groups were fed floating commercial feed twice a day to apparent satiation for 8 and 12 weeks, respectively. Water temperature was kept at $25 \pm 1{ }^{\circ} \mathrm{C}$.

\section{Results}

Water quality parameters of different experimental groups are shown in Table 1. The biofloc development was observed in terms of total suspended solids (TSS). The TSS gradually increased during the experiment. Bioflocs were observed as brown in color and were composed of suspended organic particles in the form of flocculated aggregates, which were colonized by a number of heterotrophic bacteria, microalgae, and protozoa. All the water quality parameters in the six experimental tanks were found within suitable ranges for river puffer culture throughout the experimental period.

\section{Feeding frequency}

The growth of river puffer reared at different daily feeding frequencies is shown in Table 2 . In both the 10and 40-g size groups, the final body weight, daily feed consumption, and weight gain of fish fed one meal per day were significantly lower than those of fish fed five meals per day $(P<0.05)$. However, there were no significant differences in the final body weight, daily feed

Table 1 Water quality parameters of different experimental groups

\begin{tabular}{|c|c|c|c|c|c|c|}
\hline & \multirow{2}{*}{$\begin{array}{l}\text { Feeding } \\
\text { frequency }\end{array}$} & \multirow{2}{*}{$\begin{array}{l}\text { Stocking } \\
\text { density }\end{array}$} & \multicolumn{4}{|c|}{ Water temperature } \\
\hline & & & $15^{\circ} \mathrm{C}$ & $20^{\circ} \mathrm{C}$ & $25^{\circ} \mathrm{C}$ & $30^{\circ} \mathrm{C}$ \\
\hline Temperature $\left({ }^{\circ} \mathrm{C}\right)$ & $25 \pm 1$ & $25 \pm 1$ & $15 \pm 1$ & $20 \pm 1$ & $25 \pm 1$ & $30 \pm 1$ \\
\hline Alkalinity (mg $\mathrm{CaCO}_{3}$ ) & $120 \pm 31.2$ & $132 \pm 24.7$ & $112 \pm 18.8$ & $121 \pm 23.4$ & $129 \pm 13.9$ & $127 \pm 26.3$ \\
\hline $\mathrm{pH}$ & $7.7 \pm 0.34$ & $7.5 \pm 0.27$ & $7.4 \pm 0.26$ & $7.6 \pm 0.19$ & $7.6 \pm 0.26$ & $7.5 \pm 0.31$ \\
\hline Dissolved oxygen (mg/L) & $5.57 \pm 0.26$ & $5.69 \pm 0.42$ & $6.39 \pm 0.34$ & $5.86 \pm 0.44$ & $5.49 \pm 0.32$ & $5.43 \pm 0.28$ \\
\hline Total ammonia-N (mg/L) & $0.42 \pm 1.0$ & $0.51 \pm 0.08$ & $0.36 \pm 0.06$ & $0.47 \pm 0.06$ & $0.52 \pm 0.08$ & $0.53 \pm 0.11$ \\
\hline Nitrite-N (mg/L) & $1.47 \pm 0.14$ & $0.83 \pm 0.11$ & $0.49 \pm 0.04$ & $0.53 \pm 0.04$ & $0.76 \pm 0.07$ & $0.87 \pm 0.08$ \\
\hline Nitrate-N (mg/L) & $2.89 \pm 0.13$ & $2.23 \pm 0.12$ & $1.47 \pm 0.07$ & $1.86 \pm 0.06$ & $2.47 \pm 0.11$ & $2.56 \pm 0.14$ \\
\hline Total suspended solids (mg/L) & $184 \pm 19.4$ & $167 \pm 12.7$ & $143 \pm 13.6$ & $157 \pm 17.5$ & $197 \pm 19.4$ & $201 \pm 24.1$ \\
\hline
\end{tabular}

Means and standard deviations of triplicate for each experimental group 
Table 2 The effect of feeding frequency on the growth of river puffer

\begin{tabular}{|c|c|c|c|c|c|c|c|}
\hline & \multirow[t]{2}{*}{ Treatment } & \multicolumn{2}{|c|}{ Body weight (g) } & \multirow{2}{*}{$\begin{array}{l}\mathrm{DFC}^{1} \\
(\%)\end{array}$} & \multirow{2}{*}{$\begin{array}{l}\text { Weight gain } \\
(\%)\end{array}$} & \multirow{2}{*}{$\begin{array}{l}\text { Feed efficiency }{ }^{2} \\
\text { (\%) }\end{array}$} & \multirow{2}{*}{$\begin{array}{l}\text { Survival } \\
(\%)\end{array}$} \\
\hline & & Initial & Final & & & & \\
\hline \multirow[t]{4}{*}{ 10-g size } & 1 meal per day & $8.9 \pm 0.06$ & $19.3 \pm 2.2$ & $1.29 \pm 0.18^{b}$ & $114 \pm 16.3^{b}$ & $89.7 \pm 1.54^{b}$ & $97.8 \pm 1.92^{a}$ \\
\hline & 2 meals per day & $8.8 \pm 0.03$ & $23.0 \pm 1.4$ & $1.60 \pm 0.08^{\mathrm{ab}}$ & $159 \pm 9.55^{\mathrm{ab}}$ & $93.6 \pm 2.13^{\mathrm{a}}$ & $100 \pm 0.00^{a}$ \\
\hline & 3 meals per day & $8.8 \pm 0.05$ & $21.6 \pm 2.5$ & $1.50 \pm 0.15^{\mathrm{ab}}$ & $156 \pm 17.3^{\mathrm{ab}}$ & $92.8 \pm 1.27^{\mathrm{ab}}$ & $98.9 \pm 1.92^{\mathrm{a}}$ \\
\hline & 5 meals per day & $8.8 \pm 0.07$ & $24.2 \pm 2.8$ & $1.65 \pm 0.19^{a}$ & $174 \pm 35.8^{\mathrm{a}}$ & $94.4 \pm 2.43^{\mathrm{a}}$ & $100 \pm 0.00^{a}$ \\
\hline \multirow[t]{4}{*}{ 40-g size } & 1 meal per day & $38.4 \pm 0.3$ & $61.6 \pm 5.02$ & $0.82 \pm 0.13^{b}$ & $60.4 \pm 11.9^{b}$ & $75.5 \pm 3.22^{\mathrm{a}}$ & $96.7 \pm 2.89^{a}$ \\
\hline & 2 meals per day & $38.7 \pm 0.2$ & $70.7 \pm 5.16$ & $1.04 \pm 0.12^{\mathrm{a}}$ & $82.8 \pm 14.2^{\mathrm{a}}$ & $80.6 \pm 2.75^{a}$ & $100 \pm 0.00^{a}$ \\
\hline & 3 meals per day & $38.5 \pm 0.2$ & $72.7 \pm 2.01$ & $1.10 \pm 0.04^{\mathrm{a}}$ & $88.9 \pm 5.06^{\mathrm{a}}$ & $81.3 \pm 1.86^{\mathrm{a}}$ & $100 \pm 0.00^{a}$ \\
\hline & 5 meals per day & $38.7 \pm 0.2$ & $71.3 \pm 1.94$ & $1.06 \pm 0.04^{a}$ & $84.3 \pm 4.98^{\mathrm{a}}$ & $81.0 \pm 3.44^{a}$ & $98.3 \pm 2.89^{a}$ \\
\hline
\end{tabular}

Means and standard deviations of triplicate for each experimental group. For each body weight group, values in the same column having the same superscript are not significantly different $(P<0.05)$

${ }^{1} \mathrm{DFC}=$ daily feed consumption: (final body weight - initial body weight)/[(final body weight + initial body weight) $/ 2 \times \mathrm{feeding}$ days $] \times 100$

${ }^{2}$ Feed efficiency: (weight gain/feed intake) $\times 100$

consumption, and weight gain among fish fed two, three, and five meals per day. Feed efficiency of the 10-g-size fish fed one meal per day was significantly lower than that of similar-sized fish fed two, three, and five meals per day $(P<0.05)$. However, there was no significant difference in feed efficiency among treatments for the 40-g size group. There was no significant difference in survival among treatments for both the 10- and 40-g size groups.

Table 3 shows the average feed consumption for the 10 -g-size river puffer in response to the number of daily feedings during the 8-week feeding experiment. Total feed consumption increased with increasing daily feeding frequency. However, it did not differ among the groups that were fed two, three, and five meals per day. Feed consumption at the first feeding (07:30 to 08:00) for groups that were fed three and five meals per day was almost equal and was much smaller than that for the one and two meals per day feeding groups. For the groups that were fed three and five meals per day, feed

Table 3 Feed consumption of 10-g-size river puffer in response to the number of daily feedings ( $\mathrm{g}$ )

\begin{tabular}{lllll}
\hline & $\begin{array}{l}1 \text { meal per } \\
\text { day }\end{array}$ & $\begin{array}{l}2 \text { meals per } \\
\text { day }\end{array}$ & $\begin{array}{l}3 \text { meals per } \\
\text { day }\end{array}$ & $\begin{array}{l}5 \text { meals per } \\
\text { day }\end{array}$ \\
\hline 07:30-08:00 & $317 \pm 6.76$ & $229 \pm 7.75^{\mathrm{a}}$ & $182 \pm 10.7^{\mathrm{a}}$ & $\begin{array}{l}159 \pm 7.24^{\mathrm{a}} \\
\text { 10:00-10:30 }\end{array}$ \\
12:30-13:00 & & & $125 \pm 6.14^{\mathrm{b}}$ & $79.4 \pm 7.14^{\mathrm{b}}$ \\
15:00-15:30 & & $188 \pm 9.17^{\mathrm{b}}$ & $134 \pm 9.28^{\mathrm{b}}$ & $80.4 \pm 4.04^{\mathrm{b}}$ \\
17:30-18:00 & & 417 & 441 & 473 \\
Total & 317 & 417 &
\end{tabular}

Data are the total feed consumption of each cage during the 8-week feeding experiment. Means and standard deviations of triplicate for each experimental group. Values in the same column having the same superscript are not significantly different $(P<0.05)$ consumption on and after the second feeding was much smaller than that of the first and was almost constant at each of the other feeding times, about $125 \mathrm{~g}$ for the group fed three meals per day and $78 \mathrm{~g}$ for the group fed five meals per day. Similar trends were observed for the remainder of the experimental period for the $10 \mathrm{-g}$ size group as well as the 40 -g size group.

\section{Water temperature}

The effects of water temperature on the growth of river puffer are shown in Table 4. The final body weight, weight gain, specific growth rate, and feed efficiency increased with raising water temperature up to $25^{\circ} \mathrm{C}$ and drastically decreased at $30{ }^{\circ} \mathrm{C}$ for both fish sizes. Survival rate was observed to be lower in fish reared at 20 and $30{ }^{\circ} \mathrm{C}$. However, the mortalities were apparently not the result of parasites or of a bacterial disease. The observed Q10 of SGR decreased with raising water temperature from 5.04 (temperature interval, $15-20{ }^{\circ} \mathrm{C}$ ) to 0.66 $\left(25-30{ }^{\circ} \mathrm{C}\right)$ for the 10 -g-size fish and from 4.98 to 0.31 for the 40 -g-size fish.

\section{Stocking density}

The effects of stocking density on the growth of river puffer are shown in Table 5. The final body weight for initial stocking densities of 4,8 , and $12 \mathrm{~kg} / \mathrm{m}^{3}$ was significantly higher than that of $20 \mathrm{~kg} / \mathrm{m}^{3}$ for the 10 -g-size fish, and the final stocking density reached 10.1, 19.2, 28.7 , and $39.9 \mathrm{~kg} / \mathrm{m}^{3}$, respectively. For the 40 -g-size fish, the final body weight for initial stocking densities of 3 and $6 \mathrm{~kg} / \mathrm{m}^{3}$ was significantly higher than that of 9 and $15 \mathrm{~kg} / \mathrm{m}^{3}$ and the final stocking density reached 7.38 , $13.5,17.1$, and $27.5 \mathrm{~kg} / \mathrm{m}^{3}$, respectively $(P<0.05)$. In both groups, weight gain tended to decrease with increasing stocking density and survival showed no significant difference among groups. 
Table 4 The effect of water temperature on the growth of river puffer

\begin{tabular}{|c|c|c|c|c|c|c|c|c|c|}
\hline & \multirow[t]{2}{*}{ WT $\left({ }^{\circ} \mathrm{C}\right)$} & \multicolumn{2}{|c|}{ Body weight (g) } & \multirow{2}{*}{$\begin{array}{l}\text { DFC } \\
(\%)\end{array}$} & \multirow{2}{*}{$\begin{array}{l}\text { Weight gain } \\
\text { (\%) }\end{array}$} & \multirow{2}{*}{$\begin{array}{l}\text { SGR } \\
(\%)\end{array}$} & \multirow[t]{2}{*}{ Q10 } & \multirow{2}{*}{$\begin{array}{l}\text { Feed efficiency }{ }^{2} \\
(\%)\end{array}$} & \multirow{2}{*}{$\begin{array}{l}\text { Survival } \\
(\%)\end{array}$} \\
\hline & & Initial & Final & & & & & & \\
\hline \multirow[t]{4}{*}{ 10-g size } & 15 & $10.2 \pm 0.48$ & $14.8 \pm 4.35$ & $0.65 \pm 0.06^{c}$ & $44.4 \pm 5.09^{c}$ & $0.66 \pm 0.06^{c}$ & & $61.4 \pm 3.72^{c}$ & $94.4 \pm 1.92^{b}$ \\
\hline & 20 & $10.5 \pm 0.09$ & $23.9 \pm 4.73$ & $1.39 \pm 0.06^{\mathrm{b}}$ & $128 \pm 8.45^{b}$ & $1.47 \pm 0.07^{b}$ & 5.04 & $81.7 \pm 5.64^{b}$ & $100 \pm 0.00^{\mathrm{a}}$ \\
\hline & 25 & $10.6 \pm 0.06$ & $27.4 \pm 6.04$ & $1.57 \pm 0.09^{\mathrm{a}}$ & $157 \pm 11.3^{\mathrm{a}}$ & $1.69 \pm 0.08^{\mathrm{a}}$ & 1.32 & $94.8 \pm 5.17^{\mathrm{a}}$ & $100 \pm 0.00^{\mathrm{a}}$ \\
\hline & 30 & $10.6 \pm 0.11$ & $22.8 \pm 5.17$ & $1.30 \pm 0.07^{b}$ & $115 \pm 12.8^{b}$ & $1.37 \pm 0.11^{b}$ & 0.66 & $78.3 \pm 3.99^{b}$ & $90.0 \pm 3.33^{b}$ \\
\hline \multirow[t]{4}{*}{ 40-g size } & 15 & $41.5 \pm 0.32$ & $50.1 \pm 7.31$ & $0.34 \pm 0.06^{c}$ & $20.8 \pm 2.25^{d}$ & $0.34 \pm 0.03^{c}$ & & $47.2 \pm 3.24^{c}$ & $96.7 \pm 2.89^{a b}$ \\
\hline & 20 & $40.9 \pm 0.73$ & $64.4 \pm 11.6$ & $0.80 \pm 0.11^{a}$ & $57.3 \pm 6.58^{b}$ & $0.81 \pm 0.08^{\mathrm{a}}$ & 4.98 & $62.7 \pm 4.76^{b}$ & $98.3 \pm 2.89^{\mathrm{ab}}$ \\
\hline & 25 & $41.0 \pm 0.65$ & $69.1 \pm 9.39$ & $0.91 \pm 0.08^{\mathrm{a}}$ & $68.4 \pm 5.46^{a}$ & $0.93 \pm 0.05^{\mathrm{a}}$ & 1.73 & $77.6 \pm 4.17^{a}$ & $100 \pm 0.00^{\mathrm{a}}$ \\
\hline & 30 & $41.4 \pm 0.05$ & $56.4 \pm 8.01$ & $0.55 \pm 0.08^{b}$ & $36.2 \pm 4.89^{c}$ & $0.55 \pm 0.06^{b}$ & 0.31 & $53.5 \pm 3.67^{c}$ & $90.0 \pm 5.00^{b}$ \\
\hline
\end{tabular}

Means and standard deviations of triplicate for each experimental group. For each body weight group, values in the same column having the same superscript are not significantly different $(P<0.05)$

${ }^{1}$ Specific growth rate: [(In final wt. - In initial wt. $) /$ days $] \times 100$

${ }^{2}$ Refer to Table 1

\section{Discussion}

The results of this study indicated that the growth rate and feed consumption of the river puffer, T. obscurus (between 10 and $40 \mathrm{~g}$ ), fed daily multiple diets seem to be higher than those of fish provided with a single meal. Numerous experiments have been carried out on feeding frequency in several kinds of aquaculture species (Kikuchi et al. 2006; Flood et al. 2012; Zhao et al. 2014; Kousoulaki et al. 2015), but it is difficult to make general conclusions on optimal feeding frequencies as each study has different conditions, species, and life stages of fish (Kousoulaki et al. 2015). High feeding frequency has been reported to obtain high growth by increasing feed consumption in most species (Schnaittacher et al. 2005; Seo and Lee 2008; Zhao et al. 2014). The present study was also consistent with this opinion. Different results have also reported that the highest feeding frequency did not gain the most weight in yellowtail flounder, a species with small stomachs and relatively long intestines, due to the short interval between meals (Dwyer et al. 2002). When the interval between meals is short, the food passes through the digestive tract more quickly, resulting in a less effective digestion (Zhao et al. 2014).

The effects of water temperature on the growth of fish have been examined with several kinds of fish such as the olive flounder (Fonds et al. 1995), channel catfish (Buentello et al. 2000), sea bass (Ruyet et al. 2004), parrot fish (Kim et al. 2008), and turbot (Ham et al. 2003). Generally, the growth of fish increases with raising water temperature up to a certain level and then decreases at higher temperatures as was observed in the current study and reported for other fishes (Jobling 1994a). It has also been reported that the optimum temperature for growth tended to decrease with the age of the fish (Björnsson et al. 2001; Kikuchi et al. 2006). In the current study, the optimum temperature for the growth of river puffer less than $50 \mathrm{~g}$ in body weight is around $25{ }^{\circ} \mathrm{C}$. Further research will be required with larger size fish in order to determine the effective temperature regimen needed for the production of river puffer because the commercial size of river puffer at harvest is more than $400 \mathrm{~g}$ in Korea.

Table 5 The effect of stocking density on the growth of river puffer

\begin{tabular}{|c|c|c|c|c|c|c|c|c|}
\hline & \multicolumn{2}{|l|}{ Initial } & \multicolumn{2}{|l|}{ Final } & \multirow{2}{*}{$\begin{array}{l}\text { DFC } \\
(\%)\end{array}$} & \multirow{2}{*}{$\begin{array}{l}\text { Weight gain } \\
(\%)\end{array}$} & \multirow{2}{*}{$\begin{array}{l}\text { Feed efficiency }{ }^{1} \\
\text { (\%) }\end{array}$} & \multirow{2}{*}{$\begin{array}{l}\text { Survival } \\
(\%)\end{array}$} \\
\hline & Body weight (g) & $\begin{array}{l}\text { Stocking density } \\
\left(\mathrm{kg} / \mathrm{m}^{3}\right)\end{array}$ & Body weight (g) & $\begin{array}{l}\text { Stocking density } \\
\left(\mathrm{kg} / \mathrm{m}^{3}\right)\end{array}$ & & & & \\
\hline \multirow[t]{4}{*}{ 10-g size } & $10.1 \pm 0.05$ & 4 & $25.7 \pm 0.99^{\mathrm{a}}$ & $10.1 \pm 0.39$ & $1.55 \pm 0.06^{a}$ & $154 \pm 11.0^{\mathrm{a}}$ & $96.3 \pm 3.93^{a}$ & $100 \pm 0.00^{\mathrm{a}}$ \\
\hline & $10.0 \pm 0.02$ & 8 & $24.4 \pm 2.14^{\mathrm{a}}$ & $19.2 \pm 1.68$ & $1.49 \pm 0.13^{\mathrm{a}}$ & $143 \pm 20.9^{\mathrm{ab}}$ & $87.9 \pm 5.70^{\mathrm{ab}}$ & $100 \pm 0.00^{\mathrm{a}}$ \\
\hline & $10.0 \pm 0.01$ & 12 & $24.4 \pm 2.33^{\mathrm{a}}$ & $28.7 \pm 2.74$ & $1.47 \pm 0.19^{\mathrm{ab}}$ & $134 \pm 16.7^{\mathrm{ab}}$ & $85.4 \pm 5.15^{b}$ & $98.6 \pm 2.41^{\mathrm{a}}$ \\
\hline & $10.2 \pm 0.06$ & 20 & $20.4 \pm 2.43^{b}$ & $39.9 \pm 4.77$ & $1.21 \pm 0.20^{b}$ & $118 \pm 6.31^{b}$ & $80.7 \pm 2.05^{b}$ & $98.3 \pm 2.89^{a}$ \\
\hline \multirow[t]{4}{*}{ 40-g size } & $40.5 \pm 0.32$ & 3 & $98.3 \pm 3.01^{a}$ & $7.38 \pm 0.23$ & $0.99 \pm 0.05^{\mathrm{a}}$ & $143 \pm 11.7^{a}$ & $82.8 \pm 3.40^{a}$ & $100 \pm 0.00^{a}$ \\
\hline & $40.2 \pm 0.26$ & 6 & $89.9 \pm 8.64^{a}$ & $13.5 \pm 1.30$ & $0.91 \pm 0.09^{a}$ & $124 \pm 20.3^{\mathrm{a}}$ & $80.9 \pm 4.22^{\mathrm{a}}$ & $100 \pm 0.00^{a}$ \\
\hline & $40.0 \pm 0.31$ & 9 & $75.9 \pm 3.37^{b}$ & $17.1 \pm 0.76$ & $0.74 \pm 0.04^{b}$ & $90.1 \pm 7.42^{b}$ & $78.7 \pm 3.13^{\mathrm{a}}$ & $98.1 \pm 3.21^{\mathrm{a}}$ \\
\hline & $40.0 \pm 0.28$ & 15 & $73.2 \pm 5.45^{b}$ & $27.5 \pm 2.04$ & $0.69 \pm 0.09^{b}$ & $83.6 \pm 15.2^{b}$ & $77.1 \pm 5.89^{\mathrm{a}}$ & $96.7 \pm 3.33^{\mathrm{a}}$ \\
\hline
\end{tabular}

For each body weight group, values in the same column having the same superscript are not significantly different $(P<0.05)$

'Refer to Table 1 
The Q10 of SGR obtained in the current study tended to decrease with raising water temperature and was consistent with what was reported by Jobling (1994b). The values in the same temperature range were similar for fish between 10- and 40-g initial body weight and were not largely affected by the fish size, although SGR was considerably different.

In the effects of stocking density, the numbers of fish were held constant for the duration of the experiment, and so stocking density was allowed to increase with time because of the growth of fish. Judging from the final biomass per cage, the maximum stocking densities of river puffer with BFT tanks are estimated to be more than $28 \mathrm{~kg} / \mathrm{m}^{3}$ for fish of $24-\mathrm{g}$ body weight and decreased to about $13 \mathrm{~kg} / \mathrm{m}^{3}$ for the 90 -g-size fish. The growth of river puffer in our study was affected by stocking density. Similar results have been European sea bass (Papoutsoglou et al. 1998), rock fish (Oh et al. 2013), and Amur sturgeon (Ni et al. 2014). Kikuchi et al. (2006) reported that the relationship between stocking density and growth of fish may not be uniformly positively or negatively linear for a given species. In our study, mortality showed no significant difference among different stocking densities in both the 10- and 40-g size groups. Similarly, many studies have not found any significant effects of density on survival (Gomes et al. 2006; Rafatnezhad et al. 2008; Ni et al. 2014). Kikuchi et al. (2006) reported that injuring of caudal fin was observed at high stocking densities of 8,20 , and $10 \mathrm{~kg} / \mathrm{m}^{3}$ for 8 -, 13-, and 100-g-size tiger puffers, respectively. In our study, no injury was observed in both size groups. It may be for the reason that tiger puffer has more interspecific aggression than river puffer. Meanwhile, previous studies have reported that stocking density affected skeletal anomalies (Boglione et al. 2009), metamorphosis (Hosfeld et al. 2009), sex ratios (Saillant et al. 2003), gonad development Claudia et al. 2004, egg production (Peck and Holste 2006), skin pigmentation (Doolan et al. 2008), and survival (Tagawa et al. 2004) on various fishes.

\section{Conclusions}

In the present study, the effects of feeding frequency, water temperature, and stocking density on the growth of river puffer were examined by the use of fingerlings of 10 and $40 \mathrm{~g}$ with the objective of developing effective techniques for producing river puffer in zero-exchange mixed biofloc community systems. The results of the current study showed that keeping water temperature around $25{ }^{\circ} \mathrm{C}$, stocking density less than $15 \mathrm{~kg} / \mathrm{m}^{3}$, and feeding frequency of three meals per day are suitable conditions for the production of river puffer when starting with fish that are between 10 and $90 \mathrm{~g}$ in body weight. These parameters, however, still require additional work as the suitable market size for river puffer in Korea is about $400 \mathrm{~g}$, and the results obtained in this study did not cover the full size range for commercialscale production. The results of the current study are a major first step in defining the culture parameters that are needed to establish rearing conditions of river puffer in zero-exchange mixed biofloc community systems. Further research will be necessary to understand the influence of growth on water quality control and other size classes of river puffer.

\section{Acknowledgements}

Both authors are grateful to the anonymous reviewers for their valuable advice and suggestions which helped improve this paper. This paper was also partly supported by research funds of Kunsan National University, South Korea, for the data analysis.

\section{Authors' contributions}

GYY analyzed the chemical composition and prepared the draft paper and manufactured the feed and conducted the feeding trial. JYL designed this study, the feeding system, and the revised paper. Both authors read and approved the final manuscript.

\section{Competing interests}

The authors declare that they have no competing interests.

\section{Author details}

${ }^{1}$ Chungcheongnam-do Fisheries Research Institute, Boryeong 33508, South Korea. ${ }^{2}$ Department of Aquaculture and Aquatic Science, Kunsan National University, Gunsan 54150, South Korea.

Received: 14 June 2016 Accepted: 18 June 2016

Published online: 04 July 2016

\section{References}

APHA. Standard methods for the examination of the water and wastewater (22nd edn). Washington: American Public Health Association; 1998.

Avnimelech Y. Bio-filters: the need for an new comprehensive approach. Aquac Eng. 2006:34:172-8.

Avnimelech Y. Feeding with microbial flocs by tilapia in minimal discharge bioflocs technology ponds. Aquac Eng. 2007:34:171-8.

Azim ME, Little DC. The biofloc technology (BFT) in indoor tanks: water quality, biofloc composition, and growth and welfare of Nile tilapia (Oreochromis niloticus). Aquaculture. 2008;283:29-35.

Bai SC, Wang XJ, Cho ES. Optimum dietary protein level for maximum growth of juvenile yellow puffer. Fish sci. 1999;65:380-3.

Björnsson B, Steinarsson A, Oddgeirsson M. Optimal temperature for growth and feed conversion of immature cod (Gadus morhua L.). J Mar Sci. 2001:58:29-38.

Boglione C, Marino G, Giganti M, Longobardi A, Marzi PD, Cataudella S. Skeletal anomalies in dusky grouper Epinephelus marginatus (Lowe 1834) juveniles reared with different methodologies and larval densities. Aquaculture. 2009;291:48-61.

Buentello JA, Gatlin III DM, Neill WH. Effects of water temperature and dissolved oxygen on daily feed consumption, feed utilization and growth of channel catfish (Ictalurus punctatus). Aquaculture. 2000;182:339-52.

Burford MA, Thompson PJ, Mcintosh RP, Bauman RH, Pearson DC. The contribution of flocculated material to shrimp (Litopenaeus vannamei) nutrition in a high-intensity, zero-exchange system. Aquaculture. 2004;232:525-37.

Claudia CO, Miguel RS, Miguel AON, Gutiérrez-Yurrita PJ. Effect of density and sex ratio on gonad development and spawning in the crayfish Procambarus llamasi. Aquaculture. 2004;236:331-9.

Crab R, Avnimelech Y, Defoirdt T, Bossier P, Verstraete W. Nitrogen removal techniques in aquaculture for a sustainable production. Aquaculture. 2007:270:1-14

Doolan BJ, Allan GL, Booth MA, Jones PL. Effects of cage netting colour and density on the skin pigmentation and stress response of Australian snapper Pagrus auratus (Bloch \& Schneider, 1801). Aquacult Res. 2008:39:1360-8. 
Dwyer KS, Brown JA, Parrish C, Lall SP. Feeding frequency affects food consumption, feeding pattern and growth of juvenile yellowtail flounder (Limanda ferruginea). Aquaculture. 2002;213:279-92.

Flood MJ, Purser GJ, Carter CG. The effects of changing feeding frequency simultaneously with seawater transfer in Atlantic salmon Salmo salar L. smolt. Aquaculture Int. 2012;20:29-40.

Fonds M, Tanaka M, Van der Veer HW. Feeding and growth of juvenile Japanese flounder Paralichthys olivaceus in relation to temperature and food supply. Netherlands J Sea Res. 1995;34:111-8.

Gomes LC, Chagas EC, Martins-Junior H, Roubach R, Ono EA, Lourenço JNP. Cage culture of tambaqui (Colossoma macropomum) in a central Amazon floodplain lake. Aquaculture. 2006;253:374-84.

Ham EHV, Berntssen MHG, Imsland AK, Parpour AC, Bonga SEW, Stefansson SO. The influence of temperature and ration on growth, feed conversion, body composition and nutrient retention of juvenile turbot (Scophthalmus maximus). Aquaculture. 2003;217:547-58.

Hosfeld CD, Hammer J, Handeland SO, Fivelstad S, Stefansson SO. Effects of fish density on growth and smoltification in intensive production of Atlantic salmon (Salmo salar L.). Aquaculture. 2009:294:236-41.

Jang SI, Kang HW, Han HK. Embryonic, larval, and juvenile stages in yellow puffer Takifugu obscurus. Korean J Aquaculture. 1996;9:11-8 (in Korean with English abstract)

Jobling M. Environmental factors and growth. Pages 155-168 in Fish bioenergetics. London: Chapman \& Hall; 1994a.

Jobling M. Respiration and metabolism. Pages 121-142 in Fish bioenergetics. London: Chapman \& Hall; 1994b.

Kato A, Doi H, Nakada T, Sakai H, Hirose S. Takifugu obscurus is a euryhaline fugu species very close to Takifugu rubripes and suitable for studying osmoregulation. BMC Physiology. 2005;5:18

Kikuchi K, Iwata N, Kawabata T, Yanagawa T. Effect of feeding frequency, water temperature, and stocking density on the growth of tiger puffer, Takifugu rubripes. J World Aquaculture Soc. 2006;37:12-20.

Kim KM, Lee JU, Kim JW, Han SJ, Kim KD, Jo JY. Daily feeding rates of parrot fish Oplegnathus fasciatus fed extruded pellet at the different wate temperatures. Korean J Aquaculture. 2008;21:294-8 (in Korean with English abstract).

Kousoulaki K, Sæther BS, Albrektsen S, Noble C. Review on European sea bass (Dicentrarchus labrax, Linnaeus, 1758) nutrition and feed management: a practical guide for optimizing feed formulation and farming protocols. Aquacult Nutr. 2015;21:129-51.

Little DC, Murray FJ, Azim E, Leschen W, Boyd K, Watterson A, Young JA. Option for producing a warm water fish in the UK: limit to "green growth"? Trends Food Sci Technol. 2008;19:255-64

McIntosh RP. High rate bacterial systems for culturing shrimp. Pages 117-129 in Summerfelt S.T. In: Watten BJ, Timmons MB, editors. Proceedings from the Aquacultural Engineering Society's 2001 Issues Forum. Shepherdstown: Aquaculture Engineering; 2001.

Ministry of Oceans and Fisheries. Statistical Yearbook of Maritime Affairs \& Fisheries, Sejong, Korea: Ministry of Oceans and Fisheries; 2013.

Moss SM. Marine shrimp farming in the Western Hemisphere: past problems, present solutions, and future visions. Rev Fish Sci. 2002;10:601-20.

Ni M, Haishen W, Jifang L, Meili C, Yan B, Yuanyuan R, Mo Z, Zhifei S, Houmeng D. Effects of stocking density on mortality, growth and physiology of juvenile Amur sturgeon (Acipenser schrenckii). Aquaculture Research. 2014; doi:10.1111/are.12620.

Oh DH, Song JW, Kim MG, Lee BJ, Kim KW, Han HS, Lee KJ. Effect of food particle size, stocking density and feeding frequency on the growth performance of juvenile Korean rockfish Sebastes schlegelii. Korean J Aquaculture. 2013:46:407-12 (in Korean with English abstract).

Papoutsoglou SE, Tziha G, Vrettos X, Athanasiou A. Effects of stocking density on behavior and growth rate of European sea bass (Dicentrarchus labrax) juveniles reared in a closed circulated system. Aquaculture Eng. 1998;18:135-44.

Park IS, Kim HS, Kim ES, Kim JH, Park CW. Cytogenetic analysis of river puffer, Takifugu obscurus (Teleostomi : Tetraodontiformes). J Korean Fishery Soc. 1997;30:408-12 (in Korean with English abstract).

Peck MA, Holste L. Effects of salinity, photoperiod and adult stocking density on egg production and egg hatching success in Acartia tonsa (Calanoida: Copepoda): optimizing intensive cultures. Aquaculture. 2006;255:341-50.

Rafatnezhad S, Falahatkar B, Gilani MHT. Effects of stocking density on haematological parameters, growth and fin erosion of great sturgeon juveniles. Aquacult Res. 2008;14:1506-13.
Ruyet PL, Mahé K, Le Bayon N, Le Delliou H. Effects of temperature on growth and metabolism in a Mediterranean population of European sea bass Dicentrarchus labrax. Aquaculture. 2004;237:269-80.

Saillant E, Fostier A, Haffray P, Menu B, Laureau S, Thimonier J, Chatain B. Effects of rearing density, size grading and parental factors on sex ratios of the sea bass (Dicentrarchus labrax L.) in intensive aquaculture. Aquaculture. 2003;221:183-206.

Samocha TM, Lawrence AL, Collins CA, Castille FL, Bray WA, Davies CJ, Lee PG, Wood GF. Production of the Pacific white shrimp, Litopenaeus vannamei, in high-density greenhouse-enclosed raceways using low salinity groundwater. J Appl Aquac. 2004;15:1-19.

Schnaittacher G, King WV, Berlinsky DL. The effects of feeding frequency on growth of juvenile Atlantic halibut, Hippoglossus hippoglossus L. Aquacult Res. 2005;36:370-7.

Seo JY, Lee SM. Effects of dietary macronutrient level and feeding frequency on growth and body composition of juvenile rockfish (Sebastes schlegeli). Aquac Int. 2008;16:551-60.

Son KH, Han KN, Chang CS. The changes of digestive enzyme in early stage of the river puffer, Takifugu obscurus. Korean J Fisheries Aquatic Sci. 2001:34:577-83.

Tacon AGJ, Cody JJ, Conquest LD, Divakaran S, Forster IP, Decamp OE. Effect of culture system on the nutrition and growth performance of Pacific white shrimp, Litopenaues vannamei, (Boone) fed different diets. Aquacult Nutr. 2002:8:121-37.

Tagawa M, Kaji T, Kinoshita M, Tanaka M. Effect of stocking density and addition of proteins on larval survival in Japanese flounder Paralichthys olivaceus. Aquaculture. 2004;230:517-25.

Yang Z, Chen YF. Induced ovulation in obscure puffer Takifugu obscurus by injections of LHRH-a. Aquac Int. 2004;12:215-23.

Yang Z, Chen YF. Salinity tolerance of embryos of obscure puffer Takifugu obscurus. Aquaculture. 2006;253:393-7.

Zhao S, Han D, Zhu X, Jin J, Yang Y, Xie S. Effects of feeding frequency and dietary protein levels on juvenile allogynogenetic gibel carp (Carassius auratus gibelio) var. CAS III: growth, feed utilization and serum free essential amino acids dynamics. Aquaculture Research. 2014; doi:10.1111/are.1241.

\section{Submit your next manuscript to BioMed Central and we will help you at every step:}

- We accept pre-submission inquiries

- Our selector tool helps you to find the most relevant journal

- We provide round the clock customer support

- Convenient online submission

- Thorough peer review

- Inclusion in PubMed and all major indexing services

- Maximum visibility for your research

Submit your manuscript at www.biomedcentral.com/submit 